\title{
Effect of Nitrogen Nutritional Statuses and Waterlogging Conditions on Growth Parameters, Nitrogen Use Efficiency and Chlorophyll Fluorescence in Tamarillo Seedlings
}

\author{
Jorge BETANCOURT-OSORIO, Diego SÁNCHEZ-CANRO, \\ Hermann RESTREPO-DÍAZ*
}

Universidad Nacional de Colombia, Facultad de Ciencias Agrarias, Departamento de Agronomia, Bogotá,

Colombia; hrestrepod@unal.edu.co (*correspondingauthor)

\begin{abstract}
Climate change has altered rainfall patterns causing waterlogging periods that often negatively affect the performance of horticultural crops in the Andean region in Colombia. An experiment was carried out under greenhouse conditions using three-month-old tamarillo (Solanum betaceum Cav.) seedlings, which were grown under two levels of nitrogen $(\mathrm{N})(10$ and $150 \mathrm{mg} \mathrm{N} \cdot \mathrm{L} \mathrm{H}_{2} \mathrm{O}$ ). At 28 days after transplanting (DAT), waterlogging treatments were established when well-nourished plants $\left(150 \mathrm{mg} \mathrm{N} \mathrm{L}^{-1} \mathrm{H}_{2} \mathrm{O}\right)$ significantly showed a higher shoot length than poor-nourished plants $\left(10 \mathrm{mg} \mathrm{N} \mathrm{L}^{-1} \mathrm{H}_{2} \mathrm{O}\right)(\sim 20$ $\mathrm{cm}$ vs. $\sim 10 \mathrm{~cm}$, respectively). Three different periods of waterlogging were performed between 35 and 37, 51 and 55, and 64 and 70 DAT by covering the holes in the plastic pots to ensure a constant water depth. Results showed that well-nourished plants without waterlogging treatments through the experiment's stress showed a greater shoot length $(30 \mathrm{~cm})$, total plant dry weight $(7.95 \mathrm{~g}), \mathrm{F}_{\mathrm{v}} / \mathrm{F}_{\mathrm{m}}$ ratio (0.62) and leaf chlorophyll content (37.51 SPAD units) than poor-nourished plants without stress condition $(15 \mathrm{~cm}, 5.57 \mathrm{~g}, 0.5$ and 12.69 SPAD units, respectively) at the end of the experiment. Overall, waterlogging reduced leaf area and nitrogen use efficiency (about $75 \%$ and 50\%, respectively) in both $\mathrm{N}$ levels. However, periods of waterlogging enhanced dry matter partitioning to stems (around 30-35\%) in both $\mathrm{N}$ levels. This study showed that tamarillo plants are susceptible to landscaping situations where periods of waterlogging can be expected regardless of their $\mathrm{N}$ nutritional status.
\end{abstract}

Keywords: allocation of assimilates, $\mathrm{F}_{\mathrm{v}} / \mathrm{F}_{\mathrm{M}}$ ratio, leaf area ratio, shoot length, stem diameter

\section{Introduction}

Tamarillo (Solanum betaceum Cav.) is a plant that belongs to Solanaceae family and native from Andean region. This fruit is grown commercially in countries like Brazil, Colombia, Ecuador, USA (California), Australia and New Zealand (Mejía et al., 2009; Correia and Canhoto, 2012). In Colombia, this crop occupied an area of 9000 hectares with a production of 160,000 tons in 2013 (Agronet, 2015).

Horticultural crops have been severely affected due to the increased frequency and intensity of rainfall in Colombia in recent years, as a result of climate change conditions or environmental phenomena such as La Niña, causing prolonged waterlogging periods (Floréz-Velasco et al., 2015). Waterlogging is a situation of excess water that fills soil pores and results in a reduction of available oxygen, causing different physiological responses in plants (Parad $e t$ al., 2013). Flooding has some severe consequences on plant growth and its survival strategies (Phukan et al., 2016). In this sense, the following physiological disorders have been reported under waterlogging: a lower plant growth (Aldana et al., 2014), leaf chlorophyll content (Rao and $\mathrm{Li}, 2003$ ), and total plant dry weight (Florez-Velasco et al., 2015), as well as changes in the plant water status (Striker et al., 2005). Also, waterlogging can alter biomass allocation in plants (Wu et al., 2015)

Plant nutritional status can significantly influence the plant acclimation to stressful environmental conditions. In this respect, the interaction between plant nutritional status and environmental stresses (drought, salinity, temperature, etc.) is important to understand yield losses (Cakmak, 2005). On the other hand, nitrogen $(\mathrm{N})$ is one of the most essential mineral nutrients due to its many effects on plant 
376

growth and yield (Fageria, 2001). $\mathrm{N}$ is involved in fundamental processes such as nutrients uptake, protein metabolism, photosynthesis and carbon partitioning (Maschnner, 2012). Furthermore, it has been documented that the plant $\mathrm{N}$ content decreases in plants under waterlogging conditions because $\mathrm{O}_{2}$ deficiency in the root zone can change the redox state of nutrients, making them unavailable (e.g. nitrogen) or potentially toxic for plants (Rao and Li, 2003: Najeeb et al., 2015).

Plant nutrient deficiency is the leading cause of poor plant growth under waterlogging conditions (Steffens $e t$ al. 2005). In this sense, it has been reported that an optimum $\mathrm{N}$ supply can help to ameliorate the adverse effects of waterlogging in a range of economically important crops (Percival and Keary, 2008). In wheat, a high nitrogen supply improved the plant growth compared to nonfertilized controls under waterlogging stress conditions (Huang et al., 1994). Flórez-Velasco et al., (2015) also observed that lulo plants grown with high $\mathrm{N}$ level $\left(110 \mathrm{mg} \mathrm{N} \cdot \mathrm{L}^{-1}\right)$ and subjected to waterlogging conditions showed a major plant height than plants cultivated with low nitrogen $(10 \mathrm{mg}$ $\mathrm{N} \cdot \mathrm{L}^{-1}$ ) under flooded periods. Finally, plant $\mathrm{N}$ status is essential for plant recovering after $\mathrm{O}_{2}$ deficiency in the root zone (Milroy et al., 2009).

The severity of the effects of waterlogging is also associated with the duration and/or frequency of the waterlogging event (Malik et al., 2002; Visser et al., 2003). In tomato, short periods of waterlogging (2-4 days) reduced stem growth and leaf chlorophyll content (Rao and $\mathrm{Li}$, 2003). Malik et al. (2002) also reported that even short periods (as short as $3 \mathrm{~d}$ ) of waterlogging have important long-term effects on the growth of young wheat plants. On the other hand, Ezin et al. (2010) and Aldana et al. (2014) also observed that leaf growth and plant height varied according to the flooding duration in tomato and cape gooseberry plants, respectively.

In general, studies about physiological responses of some Andean fruit trees species also belonging to Solanaceae family to waterlogging stress conditions have gained importance in recent years in Colombia due to their export potential as fresh fruit (Aldana et al., 2014; Florez-Velasco et al., 2015; Cardona et al., 2016). For that reason, it is important to enlarge the available knowledge on the interaction between nutritional status and waterlogging stress conditions (duration and/or frequency) for the economic and agricultural improvement of tamarillo plants in waterlogging affected areas. Therefore, the objective of this work was to study the interaction between $\mathrm{N}$ nutritional status and three short periods of waterlogging stress on the physiological traits of tamarillo seedlings.

\section{Materials and Methods}

\section{Generalgrowing conditions}

The present work was performed under controlled conditions in the greenhouses of the Faculty of Agricultural Sciences at Universidad Nacional de Colombia in Bogotá (2556 m.a.s.l.; $4^{\circ} 35^{\prime} 56^{\prime \prime} \mathrm{N}, 74^{\circ} 04^{\prime} 51^{\prime \prime} \mathrm{W}$ ) for 12 weeks from March to May 2012. Two-month-old 'Amarillo' tamarillo seedlings were transplanted into $1-\mathrm{L}$ plastic pots containing a mix of sand and white peat without nutrients (Base 1 substrate, Klasman-Deilmann GmbH, Geeste, Germany) in a relation $2: 1$ as substrate. Weather conditions in the greenhouse during the experiment were the following: average temperature $20 \pm$ $4{ }^{\circ} \mathrm{C}$, relative humidity between 60 and $80 \%$ and a natural photoperiod of 12 hours (photosynthetically active radiation at noon of $1600 \mu \mathrm{mol} \mathrm{m}^{-2} \mathrm{~s}^{-1}$ ).

\section{Nitrogen treatments}

At 15 days after transplanting (DAT), a group of 20 plants was chosen to establish each of the nutritional nitrogen statuses. Then, plants were watered during the experiment with $1 / 2$ Hoagland nutrient solutions with the following composition: $0.25 \mathrm{mM}$ calcium phosphate $\left[\mathrm{Ca}\left(\mathrm{H}_{2} \mathrm{PO}_{4}\right)_{2}\right], 2.5^{\circ}$ $\mathrm{mM}$ potassium chloride $(\mathrm{KCl}), 1.0 \mathrm{mM}$ magnesium sulphate $\left(\mathrm{MgSO}_{4}\right), 12.5 \mu \mathrm{M}$ boric acid $\left(\mathrm{H}_{3} \mathrm{BO}_{3}\right), 1.0 \mu \mathrm{M}$ manganese sulphate $\left(\mathrm{MnSO}_{4}\right), 1.0 \mu \mathrm{M}$ zinc sulfate $\left(\mathrm{ZnSO}_{4}\right), 0.25 \mu \mathrm{M}$ copper sulphate $\left(\mathrm{CuSO}_{4}\right), 0.2 \mu \mathrm{M}$ ammonium molybdate $\left[\left(\mathrm{NH}_{4}\right) 6 \mathrm{Mo}_{7} \mathrm{O}_{24}\right], 10 \mu \mathrm{M}$ Fe-ethylenediamine-di-o-hydroxy phenylacetic acid and either 10 (low N) or $150 \mathrm{mg} \mathrm{N} \mathrm{L}^{-1} \mathrm{H}_{2} \mathrm{O}$ (high $\mathrm{N}$ ). The two concentrations of $\mathrm{N}$ in the nutrient solutions used in this study were selected because similar ranges were employed in previous studies with the purpose of establishing low and high levels of nitrogen in plants (Belesky $e t$ al., 1984; Florez-Velasco et al., 2015). Also, the fertilizer used as a source of $\mathrm{N}$ was $46 \%$ urea (Monomeros, Barranquilla, Colombia). Furthermore, the concentration of the other macro and micronutrients of this study has also been widely used in studies of mineral nutrition (Garcia-Castro and Restrepo-Díaz, 2013).

Plants were watered twice a week, and the irrigation volume was adjusted throughout the experiment. Tamarillo plants were watered with $150 \mathrm{~mL}^{-1}$ plant $^{-1}$ week $^{-1}$ between 14 and 35 DAT and $200 \mathrm{~mL}$ plant $^{-1}$ week $^{-1}$ between 35 and 70 DAT. The water needs of the plants were estimated by the weight of the plants every 24 hours.

\section{Waterlogging treatment}

Nitrogen highly influences the growth and development of plants (Maschnner, 2013). For that reason, tamarillo plants were divided into two groups of 10 plants in each nitrogen treatment with the purpose of establishing the waterlogging conditions (with or without waterlogging) when differences on shoot length were observed between the two treatments of nitrogen fertigation $(28 \mathrm{DAT})$. Three different periods of waterlogging with duration of two, four and six days were established. The periods of low availability of oxygen in the soil were developed between 35 and 37 (S1), 51 and 55 (S2), and 64 and 70 (S3) DAT, respectively. Also, plants had a recovery time of 14 days between the first two periods of stress. The conditions of oxygen deficiency in the soil were carried out by covering the holes in the plastic pots to ensure a constant water depth of $1 \mathrm{~cm}$ over the substrate during periods of waterlogging. At the end, four groups for different treatments were available: i) well-nourished plants with $\mathrm{N}$, but without waterlogging, ii) well-nourished plants with $\mathrm{N}$ and with waterlogging stress, iii) poorly nourished plants with $\mathrm{N}$, but without waterlogging conditions and iv) poorly nourished plants with $\mathrm{N}$ and with waterlogging. In general, each treatment consisted of ten plants and the experiment lasted for 70 days. 


\section{Determined variables}

The shoot length was determined weekly from 14 to 70 DAT. At the end of the trial (70 DAT), the efficiency of photosystem II $\left(\mathrm{F}_{\mathrm{v}} / \mathrm{F}_{\mathrm{m}}\right.$ ratio) was determined by using a Fluorescence spectroscopy (Handy PEA, Hansatech Instruments, Kings Lynn, UK). Also, leaf chlorophyll content was obtained by SPAD readings as a non-destructive tool using a chlorophyll meter (SPAD-502; Minolta, Ramsey, NJ). The leaf chlorophyll content and maximum efficiency of PSII were obtained by taking a fully expanded leaf of the outer half portion of the plant. Subsequently, plants were harvested to determine the dry weights of each organ. Leaf area (LA) was also determined at the end of the experiment using a leaf area meter (LI-3100, LI -COR Inc., Lincoln, NE, USA). Likewise, the leaf area was used to calculate the leaf area ratio (LAR) by the relationship between leaf area and total plant dry weight (TPDW). Finally, nitrogen use efficiency (NUE) was also calculated using the methodology described by Florez-Velasco et al., 2015, which consisted in estimating the ratio of the total plant dry weight (TPDW) and the amount of nitrogen applied in each treatment $\left(\mathrm{NUE}=\mathrm{TPDW} / \mathrm{N}\right.$ applied, $\left.\mathrm{gg}^{-1}\right)$.

\section{Experimental design and statistical data analysis}

A factorial design with two factors (nitrogen nutritional status vs. waterlogging conditions) with ten repetitions (plants) per treatment was used. All values in percentages were transformed with the arcsine formula before the analysis. Data were analyzed using the program Statistix v. 8.0 (Analytical Software, Tallahassee, FL, U.S.). Finally, the summary of the analysis of variance of the effect of waterlogging treatments and $\mathrm{N}$ nutritional status and their interaction on the physiological response of tamarillo seedlings to waterlogging period is shown in Table 1 .

\section{Results and Discussion}

\section{Growthparameters}

Differences were observed on shoot length due to two nitrogen $(\mathrm{N})$ nutritional statuses ( $10 \mathrm{vs.} 150 \mathrm{mg} \mathrm{N} \mathrm{L}^{-1} \mathrm{H}_{2} \mathrm{O}$ ) at 28 DAT. Cultivated plants with a higher $\mathrm{N}$ content in the nutrient solution began to show a greater height until the end of the experiment (Fig. 1). Regarding the interaction between nutritional status vs. waterlogging stress, it was observed that shoot growth was lower in tamarillo plants subjected to three waterlogging periods in both $\mathrm{N}$ treatments at $70 \mathrm{DAT}$. On the other hand, stem diameter showed only differences in the $\mathrm{N}$ status factor and waterlogging treatments. A higher stem diameter was found when tamarillo seedlings were cultivated with $150 \mathrm{mg} \mathrm{N} \mathrm{L}^{-1} \mathrm{H}_{2} \mathrm{O}$. Likewise, when plants were subjected to three different periods of waterlogging, the stem diameter was also lower in comparison to plants without stressful conditions (Table 2). Aldana et al. (2014) also reported similar observations when a significant reduction in plant height and stem diameter was seen after subjecting cape gooseberry (another Solanaceae species) seedlings to eight-day waterlogging periods. Also, Florez-Velazco et al. (2015) also evaluated the effect of the interaction between waterlogging vs. nutritional $\mathrm{N}$ status and found that a series of short periods of oxygen deficiency in the soil caused a decrease in the shoot length of lulo plants (another Solanaceae species) cultivated with two levels of $\mathrm{N}$ (10 vs. $150 \mathrm{mg} \mathrm{N} \mathrm{L}^{-1} \mathrm{H}_{2} \mathrm{O}$ ), highlighting that the most significant reduction was observed in plants that were always nitrogen-deficient. A lower plant height under waterlogging conditions can be attributed to low $\mathrm{O}_{2}$ supply which causes ionic imbalance and/or nutrient stress. Also, waterlogging stress causes a decreased $\mathrm{N}$ uptake, affecting the development of the cortical cells (Rao and Li, 2003). For that reason, stem diameter could show a lower diameter in waterlogging plants. In general, several studies on the effects of flooding in crop plants have showed that morphological adjustments (such as plant height, stem diameter, adventitious roots, and hypertrophic lenticels) contribute to flood acclimatization (Liu et al., 2014; Najeeb et al., 2015; Phukan et al., 2016). In the present study, plant height and stem diameter did not increase, indicating that these lacks of changes suggest that $S$. betaceum could not achieve flood tolerance in spite of an optimum N nutritional status.

On the other hand, differences were also obtained in the $\mathrm{N}$ nutritional status vs. waterlogging interaction on leaf area and leaf area ratio (LAR) at the end of the experiment (Fig. 2). Plants cultivated with high levels of nitrogen without waterlogging had greater leaf area. Also, this variable was negatively affected by waterlogging conditions since wellnourished plants showed similar leaf area values to those obtained in plants with low nitrogen and without periods of

Table 1. Summary of analysis of variance of the effect of $\mathrm{N}$ fertigation status and waterlogging treatments on the physiological behaviour of tamarillo seedlings

\begin{tabular}{|c|c|c|c|c|}
\hline \multirow{2}{*}{ Parameter } & \multirow{2}{*}{ Abbr. } & \multicolumn{3}{|c|}{ Source of variation } \\
\hline & & Nitrogen Status $(\mathrm{N})$ & Waterlogging $(\mathrm{W})$ & $\mathrm{N} \times \mathrm{W}$ \\
\hline Leaves dry weight & LDW & $* * z$ & $* * *$ & ${ }^{*}$ \\
\hline Stems dry weight & SDW & *** & *** & ** \\
\hline Roots dry weight & RDW & N.S. & *** & N.S. \\
\hline Plant total dry weight & PTDW & ** & *** & N.S. \\
\hline Leaf area & LA & *** & *** & $* * *$ \\
\hline Leaf area ratio & LAR & ** & *** & ** \\
\hline Stem diameter & SD & *** & *** & N.S. \\
\hline Leaf chlorophyll content & SPAD & *** & * & ** \\
\hline PS II efficiency & $\mathrm{F}_{\mathrm{v}} / \mathrm{F}_{\mathrm{m}}$ & * & *** & N.S. \\
\hline Nitrogen use efficiency & NUE & *** & *** & $* * *$ \\
\hline Percentage of allocation toward leaves & & *** & *** & N.S. \\
\hline Percentage of allocation toward stem & & *** & *** & N.S. \\
\hline Percentage of allocation toward roots & & *** & N.S. & * \\
\hline
\end{tabular}


stems and petioles under waterlogging stress because flooding

excess water stress. Finally, tamarillo plants grown with $10 \mathrm{mg}$ $\mathrm{N} \mathrm{L}^{-1} \mathrm{H}_{2} \mathrm{O}$ and waterlogging had the lowest leaf area at the end of the experiment. Similar trends were also obtained in LAR. Waterlogging stress periods also caused a reduction of LAR values in tamarillo seedlings cultivated with either high or low $\mathrm{N}$. The leaf area reduction in tamarillo plants at three periods of waterlogging stress may be due to a reduction in the leaf gas exchange properties (transpiration and stomatal conductance), as observed in other Solanaceae species such as tomato (Rao and Li, 2003) and lulo (Florez-Velasco et al., 2015), causing an adverse effect on the photosynthetic capacity of the plant (Alcantara et al., 2012). Also, a lower LAR under flooding periods is due to limit nutrients uptake, producing a higher biomass allocation towards stems and/or roots (Rubio et al., 1995).

\section{Dry weights and distribution of assimilates}

Similar trends to the ones observed in leaf area and LAR were also found in the nutritional status vs. waterlogging interaction on leaves, stems, and total plant dry weight (Table 2). In general, it can be seen that plants under $N$ optimal conditions without waterlogging in soil showed higher dry weights at $70 \mathrm{DAT}$. Also, waterlogging stress reduced the accumulation of dry matter in both nutritional states (10 and $150 \mathrm{mg} \mathrm{N} \mathrm{L}^{-1} \mathrm{H}_{2} \mathrm{O}$ ). Similar results were seen in cotton (Hocking et al., 1985) and lulo (Florez-Velasco et al., 2015). Regarding roots dry weights, differences were not found between $\mathrm{N}$ nutritional status $(\mathrm{N})$ and waterlogging treatments (T). However, when dry weight data were analyzed as dry mass partitioning, it was observed that there were differences in the interaction NxT on root allocation. In general, leaves biomass allocation was negatively conditioned by waterlogging conditions or low nitrogen levels during growing (Fig. 3). In contrast, a greater accumulation of assimilates (about 40\%), was found under soil oxygen-deficiency conditions in tamarillo stems in both nutritional states. In this aspect, Trought and Drew (1980) also observed an increase in the dry matter partitioning towards wheat plant stems exposed to a short waterlogging period ( 8 days) due to a higher accumulation of carbohydrates. Bailey-Serres and Voesenek (2008) has also been reported that a re-allocating biomass (especially starch) to promotes the conversion of starch to glucose as a metabolic acclimation under $\mathrm{O}_{2}$ deprivation. Finally, a higher dry matter partition towards roots $(70 \%)$ was observed when plants were grown in an $\mathrm{N}$ deficient medium, despite the waterlogging condition. Plants often respond to nutritional stresses by increasing biomass partitioning towards their roots because more nutrients are absorbed when there is a greater root volume (Mengel and Kirkby, 2001). Poorter et al. (2012) also stated that a significant increase in biomass allocation towards roots at the expense of stem and, especially, of the leaf when nutrients are limiting. Data from this study showed that $70 \%$ of the biomass was found in roots of tamarillo plants grown in

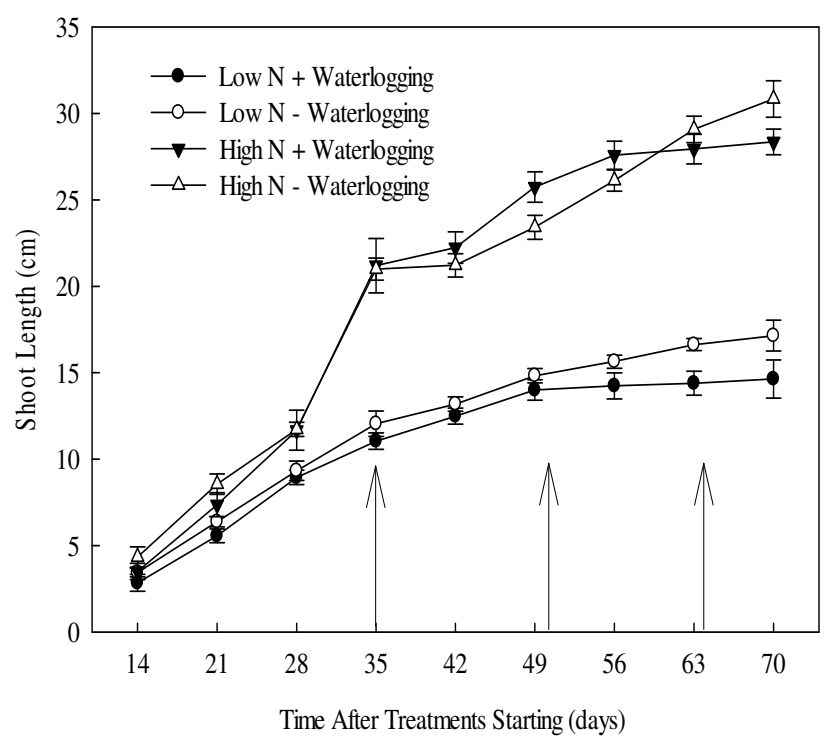

Fig. 1. Effect of the interaction between $\mathrm{N}$ nutritional status (10 (Low) and 150 (High) $\mathrm{mg} \mathrm{N} \mathrm{L}^{-1} \mathrm{H}_{2} \mathrm{O}$ ) and waterlogging conditions (with or without) on shoot length. For each treatment, the values are the mean of 10 plants \pm standard error. Arrows indicate when waterlogging stress periods started

Table 2. Effect of the interaction between $\mathrm{N}$ nutritional status ( 10 and $150 \mathrm{mg} \mathrm{N} \mathrm{L}^{-1} \mathrm{H}_{2} \mathrm{O}$ ) and waterlogging conditions (with or without) on some growth parameters (Stem Diameter (SD), Leaves Dry Weight (LDW), Stem Dry Weight (SDW), Roots Dry Weight (RDW) and Total Plant Dry Weight (TPDW)) in tamarillo seedlings at 70 days after transplanting

\begin{tabular}{|c|c|c|c|c|c|}
\hline Treatments & $\mathrm{SD}(\mathrm{mm})$ & LDW $(\mathrm{g})$ & $\mathrm{SDW}(\mathrm{g})$ & RDW (g) & TPDW $(\mathrm{g})$ \\
\hline & \multicolumn{5}{|c|}{ N nutritional status (NS) } \\
\hline $10 \mathrm{mg} \mathrm{N} \mathrm{L}^{-1} \mathrm{H}_{2} \mathrm{O}$ & $6.71^{z} a^{y}$ & $0.49 \mathrm{a}$ & $0.73 \mathrm{a}$ & 2.66 & $3.90 \mathrm{~b}$ \\
\hline $150 \mathrm{mg} \mathrm{N} \mathrm{L}^{-1} \mathrm{H}_{2} \mathrm{O}$ & $8.96 \mathrm{~b}$ & $1.36 \mathrm{~b}$ & $1.67 \mathrm{~b}$ & 2.67 & $5.70 \mathrm{a}$ \\
\hline \multirow[t]{2}{*}{ Significance $^{\mathrm{x}}$} & ${ }^{* * *}$ & *** & ${ }^{* * *}$ & N.S. & *** \\
\hline & \multicolumn{5}{|c|}{ Waterlogging treatments (WT) } \\
\hline With Waterlogging & $7.13 \mathrm{a}$ & $0.37 \mathrm{~b}$ & $0.94 \mathrm{a}$ & $1.53 \mathrm{a}$ & $2.85 \mathrm{~b}$ \\
\hline Without Waterlogging & $8.55 \mathrm{~b}$ & $1.49 \mathrm{~b}$ & $1.44 \mathrm{~b}$ & $3.81 \mathrm{~b}$ & $6.76 \mathrm{a}$ \\
\hline \multirow[t]{2}{*}{ Significance } & ${ }^{* * *}$ & ${ }^{* * *}$ & *** & ${ }^{* * *}$ & ${ }^{* * *}$ \\
\hline & \multicolumn{5}{|c|}{ NS $x$ WT } \\
\hline $10 \mathrm{mg} \mathrm{N} \mathrm{L}^{-1} \mathrm{H}_{2} \mathrm{O} \times$ With Waterlogging & 6.08 & $0.21 \mathrm{~b}$ & $0.62 \mathrm{c}$ & 1.41 & $2.24 \mathrm{~d}$ \\
\hline $10 \mathrm{mg} \mathrm{N} \mathrm{L}^{-1} \mathrm{H}_{2} \mathrm{O} \times$ Without Waterlogging & 7.35 & $0.79 \mathrm{~b}$ & $0.83 \mathrm{c}$ & 3.94 & $5.57 \mathrm{~b}$ \\
\hline $150 \mathrm{mg} \mathrm{N} \mathrm{L}^{-1} \mathrm{H}_{2} \mathrm{O} \times$ With Waterlogging & 8.17 & $0.53 \mathrm{~b}$ & $1.26 \mathrm{~b}$ & 1.66 & $3.45 \mathrm{c}$ \\
\hline $150 \mathrm{mg} \mathrm{N} \mathrm{L}^{-1} \mathrm{H}_{2} \mathrm{O} \times$ Without Waterlogging & 9.75 & $2.19 \mathrm{a}$ & $2.08 \mathrm{a}$ & 3.67 & $7.95 \mathrm{a}$ \\
\hline Significance & N.S. & ${ }^{* * *}$ & ** & NS & * \\
\hline
\end{tabular}

${ }^{\bar{z}}$ For all treatments, values are the mean of 10 replicates.

${ }^{y}$ Means with different letters represent statistically significant differences according to Tukey's test $(\mathrm{p} \leq 0.05)$.

$\mathrm{x}^{*},{ }^{* *}$, and ${ }^{* * *}$ significantly different at the $0.05,0.01$ and 0.001 probability levels, respectively. NS, not significant at $\alpha=0.05$. 
an $\mathrm{N}$ deficient medium $\left(10 \mathrm{mg} \mathrm{N} \mathrm{L}^{-1} \mathrm{H}_{2} \mathrm{O}\right)$ in both conditions of waterlogging. Similar observations were found in lulo by Parra-Coronado et al. (2015) where they reported that $70 \%$ of the dry matter was accumulated in roots under $\mathrm{N}$ deficiency.

\section{Chlorophyll content, chlorophyll fluorescence and NUE}

Tamarillo plants grown with a high nitrogen concentration and without waterlogging periods showed the highest SPAD readings at the end of the experiment (Table 3). In this context, a low chlorophyll content under waterlogging stress may be because this abiotic stress condition causes a significant decrease in the $\mathrm{N}$ uptake due to a reduced root activity (Rao and $\mathrm{Li}$, 2003). On the other hand, plants grown with a low $\mathrm{N}$ solution and without low oxygen availability conditions in the soil had the highest nitrogen use efficiency (NUE). NUE was reduced to $50 \%$ by waterlogging periods in tamarillo plants in both $\mathrm{N}$ levels. In this sense, the effect of the waterlogging vs. $\mathrm{N}$ nutritional status interaction has also been reported by FlorezVelasco et al. (2015) in lulo seedlings. They found that NUE was also higher when plants were grown under low $\mathrm{N}$. A higher NUE in tamarillo plants cultivated in an $\mathrm{N}$ deficient medium can be due to the fact that NUE tends to increase when the N input decreases, since the plant tries to optimize its $\mathrm{N}$ absorption through a high-affinity nitrate transport system (Mi et al., 2007). On the other hand, our results also showed that waterlogging caused a lower NUE. Under flooded conditions, the bioavailability of $\mathrm{N}$ decreases due to dilution and leaching
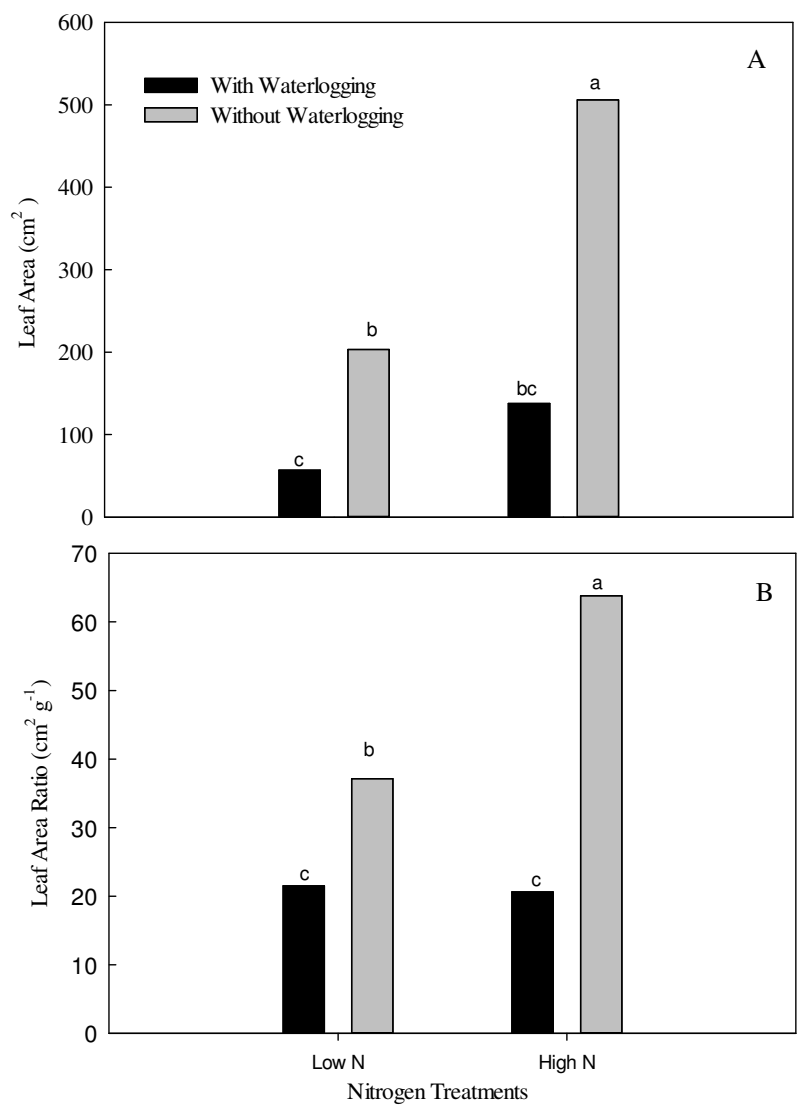

Fig. 2. Influence of the interaction $\mathrm{N}$ nutritional status between (10 (Low) and 150 (High) $\mathrm{mg} \mathrm{N} \mathrm{L}^{-1} \mathrm{H}_{2} \mathrm{O}$ ) and waterlogging conditions (with or without) on leaf area $(\mathrm{A})$ and leaf area ratio (B). Each bar chart represents the mean of 10 plants. Vertical bars represent \pm standard error

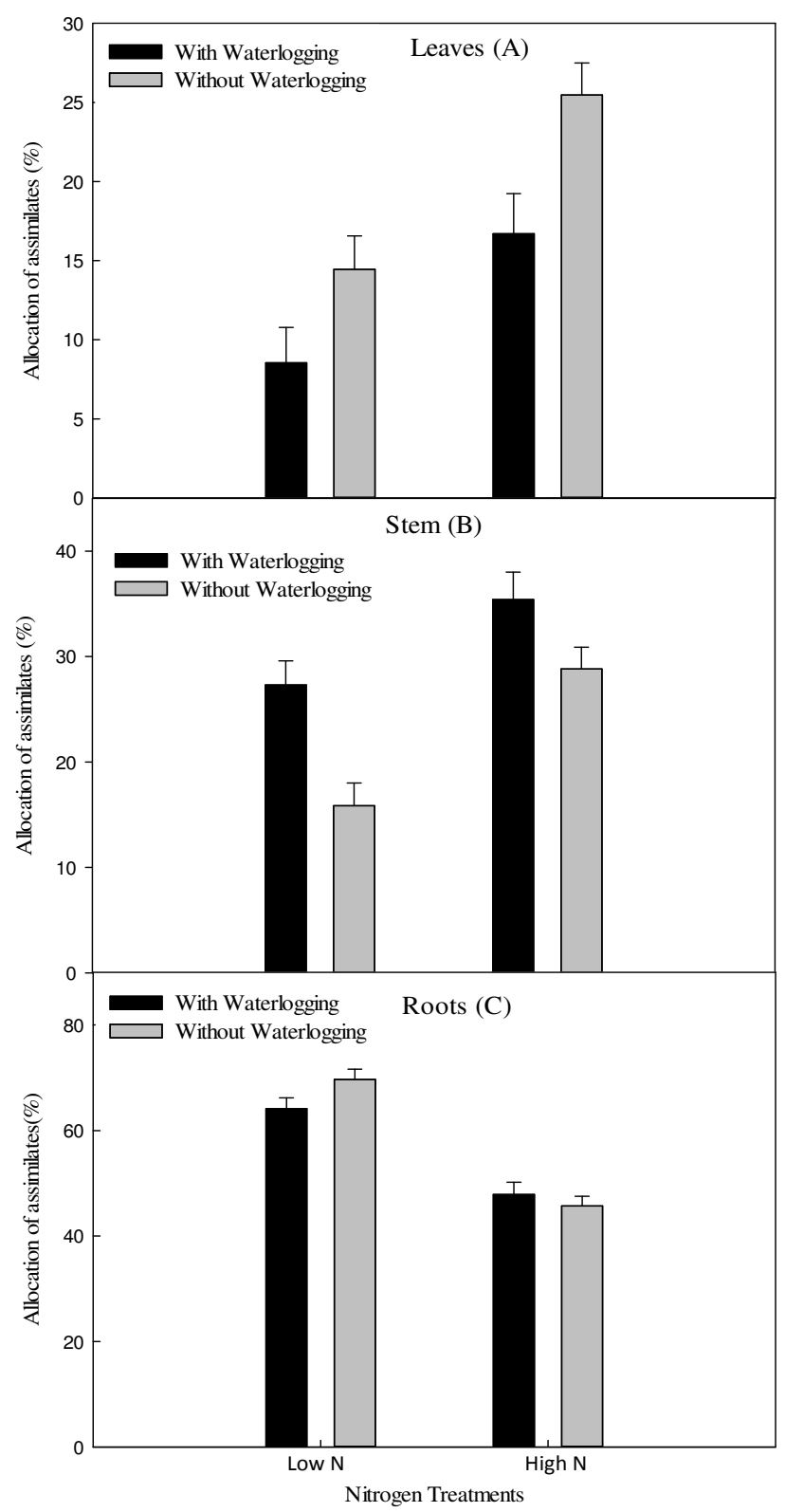

Fig. 3. Influence of the effect of the interaction between (10 (Low) and 150 (High) $\mathrm{mg} \mathrm{N} \mathrm{L}^{-1} \mathrm{H}_{2} \mathrm{O}$ ) and waterlogging conditions (with or without) on the percentage of dry mass allocation toward leaves (A), stems (B) and roots (C) in tamarillo seedlings. Each bar chart represents the mean of 10 plants. Vertical bars represent \pm standard error

(Liu et al., 2013). Also, it is important to consider that under $\mathrm{O}_{2}$ deficiency in the root zone can change the redox state of nutrients, making them unavailable (e.g. nitrogen) (Najeeb et al., 2015).

Differences were separately observed on $\mathrm{F}_{\mathrm{v}} / \mathrm{F}_{\mathrm{m}}$ ratio due to $\mathrm{N}$ nutritional status, or three short periods of waterlogging. $\mathrm{F}_{\mathrm{v}} / \mathrm{F}_{\mathrm{m}}$ ratio diminished when plants were subjected to low $\mathrm{N}$ or waterlogging conditions (Fig 3). Studies have shown that chlorophyll fluorescence is a good indicator of nutrient stresses (Gorbe and Calatayud, 2012). Parra-Coronado et al. (2015) also found that $\mathrm{F}_{\mathrm{v}} / \mathrm{F}_{\mathrm{m}}$ ratio was lower under nitrogen deficiency in lulo. Furthermore, Lima et al. (1999) stated that a drop in 
380

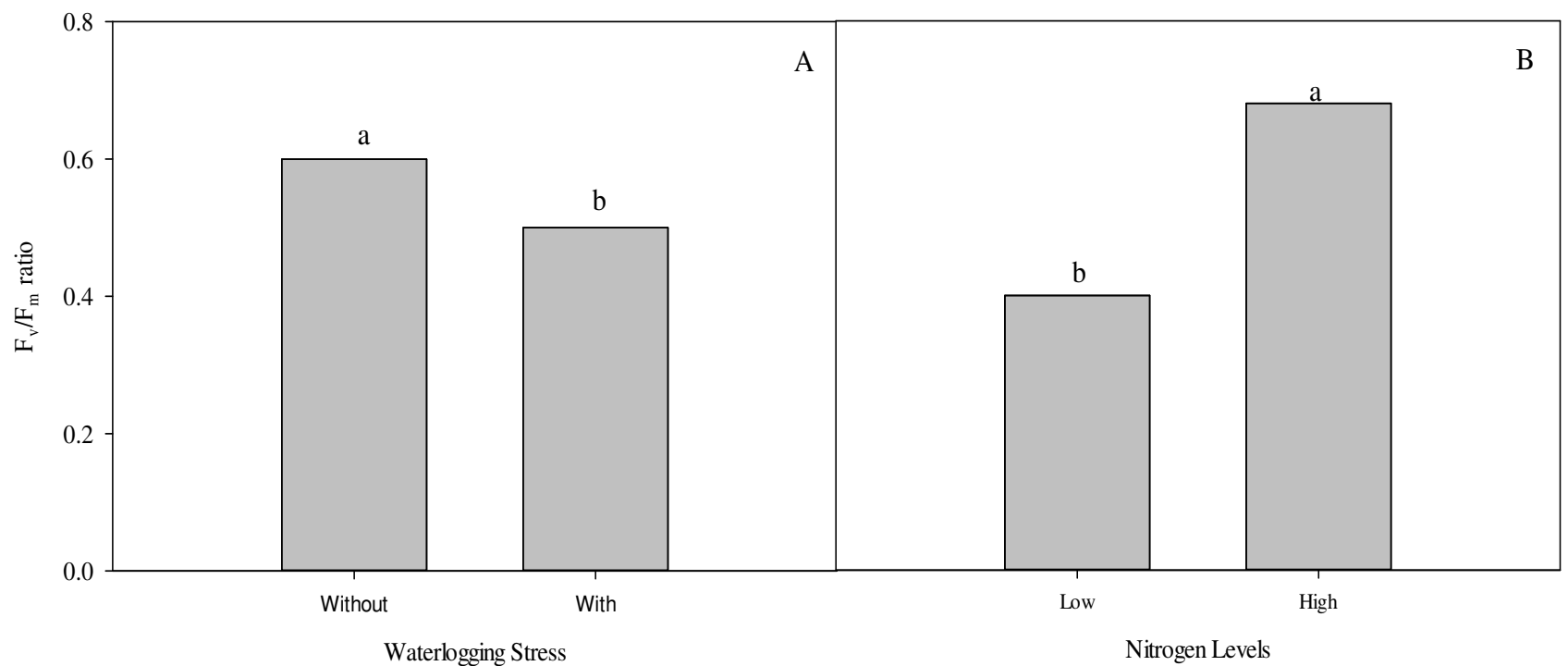

Fig. 4. Influence of the effect of the interaction between waterlogging conditions (with or without) (A) and Nitrogen Levels (10 (Low) and 150 (High) $\left.\mathrm{mg} \mathrm{N} \mathrm{L}^{-1} \mathrm{H}_{2} \mathrm{O}\right)(\mathrm{B})$ on $\mathrm{F}_{\mathrm{v}} / \mathrm{F}_{\mathrm{m}}$ ratio. Each bar chart represents the mean of 20 leaves replicates. Vertical bars represent \pm standard error

Table 3. Effect of the interaction between $\mathrm{N}$ nutritional status ( 10 and $110 \mathrm{mg} \mathrm{N} \mathrm{L}^{-1} \mathrm{H}_{2} \mathrm{O}$ ) and waterlogging conditions (with or without) on leaf chlorophyll content (SPAD readings) and Nitrogen Use Efficiency (NUE) in tamarillo seedlings at 70 days after transplanting

\begin{tabular}{lcc}
\hline Treatments & $\begin{array}{c}\text { SPAD } \\
\text { Readings }\end{array}$ & $\begin{array}{c}\text { NUE } \\
\left(\mathrm{g} \mathrm{DW}^{-1}\right)\end{array}$ \\
\hline $10 \mathrm{mg} \mathrm{N} \mathrm{L}^{-1} \mathrm{H}_{2} \mathrm{O} \times$ Without Waterlogging & $12.69 \mathrm{c}^{\mathrm{z}}$ & \\
$10 \mathrm{mg} \mathrm{N} \mathrm{L}^{-1} \mathrm{H}_{2} \mathrm{O} \times$ With Waterlogging & $10.63 \mathrm{c}$ & $15.46 \mathrm{~b}$ \\
$150 \mathrm{mg} \mathrm{N} \mathrm{L}^{-1} \mathrm{H}_{2} \mathrm{O} \times$ Without Waterlogging & $37.51 \mathrm{a}$ & $4.98 \mathrm{c}$ \\
$150 \mathrm{mg} \mathrm{N} \mathrm{L}^{-1} \mathrm{H}_{2} \mathrm{O} \times$ With Waterlogging & $23.82 \mathrm{~b}$ & $2.18 \mathrm{c}$ \\
\hline
\end{tabular}

${ }^{\mathrm{z}}$ Means with different letters represent statistically significant differences according to Tukey's test $(\mathrm{p} \leq 0.05)$.

the $\mathrm{F}_{\mathrm{v}} / \mathrm{F}_{\mathrm{m}}$ ratio might be caused by chlorophyll loss and a low nitrogen content created by an imbalance in the allocation of assimilated nutrients. This theory could also be applied to the poor-nourished plants $\left(10 \mathrm{mg} \mathrm{N} \mathrm{L}^{-1} \mathrm{H}_{2} \mathrm{O}\right)$ in the present trial, which demonstrated a lower $\mathrm{F}_{\mathrm{v}} / \mathrm{F}_{\mathrm{m}}$ ratio, as these plants had a lower chlorophyll content (Fig. 3) and accumulated less LDW (Table 2). As it was mentioned above, $F_{v} / F_{m}$ ratio was conditioned by waterlogging treatments. Malik et al. (2015) observed that the PSII efficiency was also negatively affected by waterlogging. Also, Irfa et al. (2010) mentioned that a lower $\mathrm{F}_{\mathrm{v}} / \mathrm{F}_{\mathrm{m}}$ ratio under waterlogging conditions may be due to an increase in the ethylene concentration in leaves because 1aminocyclopropane-1-carboxilic acid (ACC, a precursor of ethylene) is synthesized and then transported in the xylem to the aerial part where it is rapidly oxidized to ethylene in anaerobic conditions (Ahmed et al., 2006).

\section{Conclusions}

In general, this study also showed that a lower shoot length, stem diameter, leaf area, total plant dry weight, $N U E, F_{v} / F_{m}$ ratio and chlorophyll content either with a low or high $\mathrm{N}$ status. This lack of response in the physiological traits under waterlogging conditions indicates that $S$. betaceum plants could not achieve a flood tolerance mechanism, allowing inferring that this species is susceptible to landscaping situations where periods of waterlogging can be expected in spite of an adequate nitrogen nutrition.

\section{References}

Ahmed S, Nawata E, Sakuratani T (2006). Changes of endogenous ABA and ACC, and their correlations to photosynthesis and water relations in mungbean (Vigna radiata (L.) Wilczak cv. KPS1) during waterlogging. Environmental and Experimental Botany 57:278-284.

Agronet (2015). Sistema de Estadísticas Agropecuarias - SEA. Retrieve 2016 June 17 from http://urww.agronet.gov.co/agronetweb1/Estadisticas.aspx.

Aldana F, García PN, Fischer G (2014). Effect of waterlogging stress on the growth, development and symptomatology of cape gooseberry (Physalis peruviana L.) plants. Revista de la Academia Colombiana de Ciencias Físicas, Exactasy Naturales 38:393-400.

Bailey-Serres J, Voesenek LACJ (2008). Flooding stress: acclimations and genetic diversity. Annual Review of Plant Biology 59:313-339.

Belesky DP, Fishman ML, Wilkinson SR (1984). Effect of nitrogen fertilization and mild water stress on the distribution of nitrogen in tall fescue. Plant and Soil 77:295-303.

Cakmak I (2005). The role of potassium in alleviating detrimental effects of abiotic stresses in plants. Journal of Plant Nutrition and Soil Science 168:521-530. 
Cardona WA, Bautista-Montealegre LG, Florez-Velasco N, Fischer G (2016). Biomass and root development response of lulo (Solanum quitoense var. septentrionale) plants to shading and waterlogging. Revista Colombiana de Ciencias Horticolas 10:53-65.

CorreiaSI, Canhoto JM (2012). Biotechnology of tamarillo (Cyphomandra betacea): from in vitro cloning to genetic transformation. Scientia Horticulturae 148:161-168.

Ezin V, De La Pena R, Ahanchede A (2010). Flooding tolerance of tomato genotypes during vegetative and reproductive stages. Brazilian Journal of Plant Physiology 22:131-142.

Fageria VD (2001). Nutrient interactions in crop plants. Journal of Plant Nutrition 24:1269-1290.

Flórez-Velasco N, Balaguera-López HE, Restrepo-Díaz H (2015). Effects of foliar urea application on lulo (Solanum quitoense cv. Septentrionale) plants grown under different waterloging and nitrogen conditions. Scientia Horticulturae 186:154-162.

Garcia-Castro A, Restrepo-Díaz H (2013). Evaluation of fertilization with uncoated urea and 3,4-dimethylpyrazole phosphate (DMPP)-coated urea on nitrogen leaching and rose (Rosa spp.) yield. Chilean Journal of Agricultural Research 73:154159.

Gorbe, E, Calatayud A (2012). Applications of chlorophyll fluorescence imaging technique in horticultural research: A review. Scientia Horticulturae 138:24-35.

Hocking PJ, Reicosky DC, Meyer WS (1985). Nitrogen status of cotton subjected to two short term periods of waterlogging of varying severity using a sloping plot water-table facility. Plant and Soil 87:375-391.

Huang B, Johnson JW, NeSmith DS, Bridges DC (1994). Growth, physiology and anatomical responses of two wheat genotypes to waterlogging and nutrient supply. Journal of Experimental Botany 45:193-202.

Irfan M, Hayat S, Hayat Q, Afroz S, Ahmad A (2010). Physiological and biochemical changes in plants under waterlogging. Protoplasma 241:317.

Lima JD, Mosquim PR, Da Matta FM (1999). Leaf gas exchange and chlorophyll fluorescence parameters in Phaseolus vulgaris as affected by nitrogen and phosphorus deficiency. Photosynthetica37:113-121.

Liu G,LiY, Migliaccio K, Olczyk T, Alva A (2013). Oxygen amendment on growth and nitrogen use efficiency of flooded Italian Basil. International Journal of VegetableScience 19:217-227.

Liu Z, Cheng R, Xiao W, Guo Q, Wang N (2014). Effect of off-season flooding on growth, photosynthesis, carbohydrate partitioning, and nutrient uptake in Distylium chinense. PLoSOne 9:e107636.

Malik AI, Colmer TD, Lambers H, Setter TL, Schortemeyer M (2002). Short-term waterlogging has long-term effects on the growth and physiology of wheat. New Phytologist 153:225-236.

Malik AI, Ailewe TI, Erskine W (2015). Tolerance of three grain legume species to transient waterlogging $\mathrm{AOB}$ plants. doi: 10.1093/aobpla/plv040.

Marschner P (2012). Marschner's Mineral Nutrition of Higher Plants. Academic Press, London.
Mejía DM, Rodas EI, Patiño LF, Gonzalez EP (2009). Efecto del acibenzolar-s-metil sobre el desarrollo de la virosis causada por potyvirus en tomate deárbol. Agronomía Colombiana 27:87-93.

Mengel K, Kirkby EA (2001). Principles of Plant Nutrition. Kluwer Academic Publishers, London.

Mi G, Chen F, Zhang F (2007). Physiological and genetic mechanisms for nitrogen use efficiency in maize. Journal of Crop Science and Biotechnology 10:57-63.

Milroy SP, Bange MP, Thongbai P (2009). Cotton leaf nutrient concentrations in response to waterlogging under field conditions. Field Crops Research 113:246-255.

Najeeb U, Bange MP, Tan DKY, Atwell BJ (2015). Consequences of waterloging in cotton and opportunities for mitigation of yield losses. AoBPlants 7.doi:10.1093/aobpla/plv080.

Parad GA,Zarafshar M, Striker GG, Sattarian A (2013). Some physiological and morphological responses of Pyrus boissieriana to flooding. Trees 27(5):1387-1393.

Parra-Coronado A, Ardila-Roa GH, Restrepo-Díaz, H (2015). The physiological response of lulo plants (Solanum quitoense var. Septentrionale) to soil and foliar applications of nutrients. International Journal of Fruit Science 145:148-160.

Percival GC, Keary IP (2008). The influence of nitrogen fertilization on waterlogging stresses in Fagus sylvatica L. and Quercus robur L. Arboriculture and Urban Forestry 34:29-40.

Phukan U, Mishra S, Shukla RK (2016). Waterlogging and submergence stress: affects and acclimation. Critical Reviews in Biotechnology 36:956966.

Poorter H, Niklas KJ, Reich PB, Oleksyn J, Poot P, Mommer L (2012). Biomass allocation to leaves, stems and roots: meta-analyses of interspecific variation and environmental control. New Phytologist 193:30-50.

Rao R, Li Y (2003). Management of flooding effects on growth of vegetable and selected field crops. Hort Technology 13:610-616.

Rubio G, Cassasol G, Lavado RS (1995). Adaptations and biomass production of two grasses in response to waterloging and soil nutrient enrichment. Oecologia 102:102-105.

Steffens D, Hutsch BW, Eschholz T, Losak T, Schubert S (2005). Waterlogging may inhibit plant growth primarily by nutrient deficiency rather than nutrient toxicity. Plant Soil and Environment 51:545-552.

Striker GG, Insausti P, Grimoldi AA, Ploschuk EL, Vasellati V (2005). Physiological and anatomical basis of differential tolerance to soil flooding of Lotus corniculatus L. and Lotus glaber Mill. Plant and Soil 276:301-311.

Trought MCT, Drew, MC (1980). The development of waterlogging damage in wheat seedlings (Triticum aestivum L.): I. Shoot and root growth in relation to changes in the concentrations of dissolved gases and solutes in the soil solution. Plant and Soil 54:77-94.

Visser EJW, Voesenek ACJ, Vartapetian B, Jackson MB (2003). Flooding and plant growth. Annals of Botany 91:107-109. 